\title{
Construction of a molecular identification profile of new varieties of Nierembergia linariaefolia by anchored microsatellites
}

\author{
Mariana C. Pérez de la Torre \\ Instituto de Floricultura \\ INTA Castelar \\ Nicolás Reppetto y De los Reseros s/n. (1712) \\ Buenos Aires, Argentina \\ Tel/Fax: 541146813736 \\ E-mail: mpdelatorre@cnia.inta.gov.ar \\ Alejandro S. Escandón* \\ Instituto de Floricultura \\ INTA Castelar \\ Nicolás Reppetto y De los Reseros s/n. (1712) \\ Buenos Aires, Argentina \\ Tel/Fax: 541146813736 \\ E-mail: aescandon@cnia.inta.gov.ar
}

Web site: http://www.inta.gov.ar

Financial support: Granted by INTA Project number 1837 .

Keywords: ISSR, ornamentals, varietal identification.

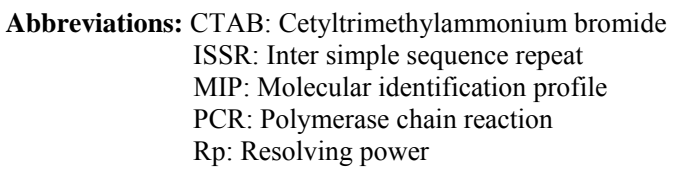

Abbreviations: CTAB: Cetyltrimethylammonium bromide ISSR: Inter simple sequence repeat MIP: Molecular identification profile PCR: Polymerase chain reaction Rp: Resolving power

The objective of the present work was to establish the molecular identification profile for six new varieties of Nierembergia linariaefolia to incorporate the fingerprint, as complementary information to the standard registration data. Total DNA was extracted from young leaves following the protocol of the cetyltrimethylammonium bromide. Anchored microsatellites were used as molecular markers. The amplification reactions were carried out with seven primers. A total of 251 loci were detected, $98 \%$ of them were polymorphic. The average of polymorphic loci was 35 loci per primer and, 41 loci per genotype. Six out of the seven primers used discriminated all the individuals involved in the present study; consequently, it was possible to generate the molecular identification profile for the six new varieties. This result, supported together with our previous reports, indicates that the anchored microsatellites are a very useful technique for the fingerprints generation in $N$. linariaefolia.

The genus Nierembergia, a member of the Solanaceae family, comprises about 21 species, 15 of them are natives from Argentina (Cocucci, 1995). The distribution centre of this specie is located in the central region of the country (Zuloaga and Morrone, 1999).

Four species of the genus Nierembergia were incorporated to the native ornamental plants breeding program: $N$. rivularis, $N$. tandilensis, $N$. calycina and $N$. linariaefolia, which is the most advance in the breeding process.

Based on the abundant and length of the flowering period, the variability in the colour of the flowers and the easiness of propagation six new varieties of $N$. linariaefolia were selected. Four of these varieties ("Nube", "Luna", "Estrella" and "Cielo") are already registered, whereas the remainders ("Bruma" and "Nieve") are under registration process. Into this context, the molecular markers for varietal identification can be used as a tool to avoid the fraudulent multiplications as well as to preserve property rights, and they have become a complement of the traditional methods based on observable characters of the plants (Cenis, 2000).

The ISSR markers (Zietkiewicz et al. 1994) are generated

* Corresponding author 
from single-primer PCR reactions where the primer is designed from di- or trinucleotide repeat motifs with a $5^{\prime}$ or 3 ' anchoring sequence of one to three nucleotides (Wolfe et al. 1998), without the requirement for prior sequence information (McGregor et al. 2000). Its application as PCR primer revealed high polymorphism degree (Zietkiewicz et al. 1994), generating reliable information for DNA analysis and with the necessary sensibility to distinguish among individuals genetically related (Pérez de la Torre et al.

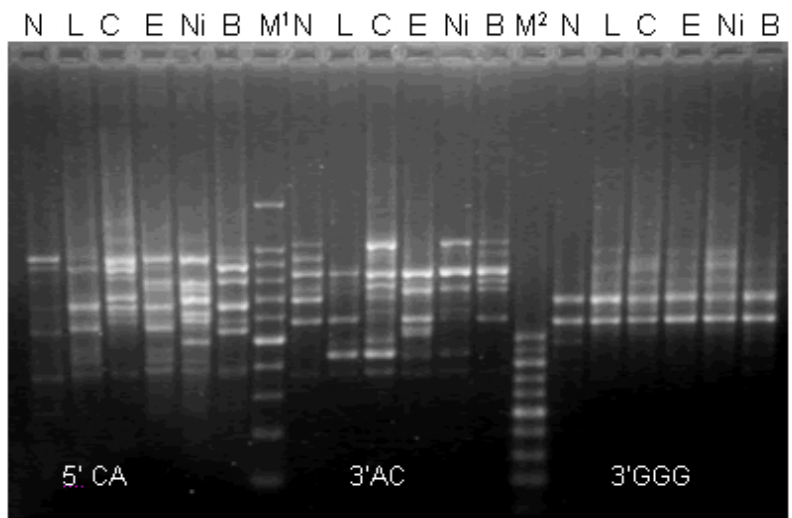

Figure 1. Amplification products obtained from six varieties of $\boldsymbol{N}$. linariaefolia using primers $5^{\prime} \mathrm{CA}, \mathbf{3}^{\prime} \mathrm{AC}$ and $3^{\prime} \mathrm{GGG}$. N: var. Nube, L: var. Luna, C: var. Cielo, Ni: var. Nieve, B: var. Bruma, $M^{1}: 100$ bp ladder, $M^{2}: 50$ bp ladder.

2003).

This technique was successfully applied to the study of Astragalus oniciformi populations (Alexander et al. 2004), Penstemon sp (Wolfe et al. 1998) and in taxonomic studies of Vigna (Ajibade et al. 2000). In ornamental species ISSRs have been used in Jacaranda sp (Pérez de la Torre et al. 2003; Escandón et al. 2005a), Nierembergia (Escandón et al. 2005b), Pandorea sp (Jain et al. 1999) and Chrysantemum (Wolff et al. 1995). The ISSR strategy was applied to generate fingerprints in selected clones of $N$. linariaefolia, supported by the reproducibility of the banding patterns compared to the RAPD's ones, being the longer primers and the higher annealing temperature the probable causes of this difference (Nybon, 2004).

The objective of the present work was to establish a MIP to add to the classical variety descriptors as complementary information for cultivar registration.

\section{MATERIALS AND METHODS}

\section{Plant material and DNA isolation}

Total DNA was extracted following the CTAB procedure according to CIMMYT, Laboratory Protocols (2005). Young leaves of $N$. linariaefolia var. Nube INTA-JICA, Luna INTA-JICA, Estrella INTA-JICA, Cielo INTA-JICA, Nieve INTA-JICA and Bruma INTA-JICA were frozen with liquid nitrogen and ground using mortar and pestle. DNA quality was assessed by running $0.8 \%$ agarosa gels stained with Ethidium Bromide (1/100 v/v), using $\lambda$ Hind III as molecular weight pattern.

\section{Polymerase chain reaction}

Seven ISSR primers were used in the present study: $5^{\prime} \mathrm{CT}$ : CCGGATCC(CT) ${ }_{9}$ (Pérez de la Torre et al. 2003), 5'GT: CCCGGATCC(GT) $)_{9}$ 5'GA: CCCGGATCC(GA) $)_{9}$, 5'CA: CCCGGATCC(CA), 3'GA: (GA) ${ }_{9} \mathrm{~T}$ (Blair et al. 1999), 3'AC: (AC) ${ }_{8} \mathrm{G}, 3^{\prime} \mathrm{GGG}$ : $\mathrm{GGG}(\mathrm{TGGGG})_{2} \mathrm{TG}$ (University of British Columbia, UBC).

PCR reactions were carried out in a final volume of $25 \mu \mathrm{l}$ containing $30 \mathrm{ng}$ of total DNA; $0.5 \mathrm{U}$ Taq polymerase (InBio-Unicem, Tandil, Argentina); $2.5 \mu 1$ of $10 \mathrm{X}$ reaction buffer (InBio-Unicem, Tandil, Argentina); $0.2 \mathrm{mM}$ of dNTP's; $0.8 \mu \mathrm{M}$ primers and $3.0 \mathrm{mM} \mathrm{MgCl}_{2}$. DNA amplifications were performed in an Eppendorf thermocycler (Mastercycler personal) with a preliminary step of $10 \mathrm{~min}$ at $94^{\circ} \mathrm{C}$, for the primers $3^{\prime} \mathrm{AC}$ and $3^{\prime} \mathrm{GGG}$ a touch down from $47^{\circ} \mathrm{C}$ to $42^{\circ} \mathrm{C}$ was done, $45 \mathrm{sec}$ at $47^{\circ} \mathrm{C}$, $90 \mathrm{sec}$ at $72^{\circ} \mathrm{C}$ and $40 \mathrm{sec}$ at $94^{\circ} \mathrm{C}$, followed by 40 cycles with the following conditions: $40 \mathrm{sec}$ at $94^{\circ} \mathrm{C}, 45 \mathrm{sec}$ at $42^{\circ} \mathrm{C}, 90 \mathrm{sec}$ at $72^{\circ} \mathrm{C}$ and a final $10 \mathrm{~min}$ extension at $72^{\circ} \mathrm{C}$. For the other primers $\left(5^{\prime} \mathrm{GA} ; 5^{\prime} \mathrm{CT} ; 5^{\prime} \mathrm{GT}, 5^{\prime} \mathrm{CA}\right.$ and $\left.3^{\prime} \mathrm{GA}\right)$ the PCR conditions were: initial step of $10 \mathrm{~min}$ at $94^{\circ} \mathrm{C}$, and 40 cycles with $40 \mathrm{sec}$ at $94^{\circ} \mathrm{C}, 45 \mathrm{sec}$ at $57^{\circ} \mathrm{C}, 90 \mathrm{sec}$ at $72^{\circ} \mathrm{C}$ and a final $10 \mathrm{~min}$ extension at $72^{\circ} \mathrm{C}$.

$10 \mu \mathrm{l}$ of PCR products were analyzed on $2.5 \%$ agarose gels in TAE buffer running at $60 \mathrm{~V}$ for $240 \mathrm{~min}$. Gels were stained with Ethidium Bromide $(5 / 100 \mathrm{v} / \mathrm{v})$. The bands obtained were sized (in base pairs) by comparison with standard marker (100 bp and 50 bp ladder, PB-L, UNQ, Quilmes, Argentina).

For the analysis only the well defined and reproducible bands were considered. Bands with the same migration distance were considered homologous fragments, independently of their intensity. The analysis was performed in a visual way, with the support of the program for calculation of molecular weight designed by Dr. Jorge Dubcovsky (Professor of Agronomy and Extension Department of California University, Davis, USA). Accordingly the presence of a band was scored as "1" while the absence of the band was scored as " 0 ", representing null-alleles. Data sets derived from the respective banding patterns were used to generate a basic data matrix for each accession.

The power of each ISSR primer to distinguish among the studied genotypes was evaluated by the Resolving Power (Rp) (Prevost and Wilkinson, 1999). It is defined per primer as: $\mathrm{Rp}=\Sigma \mathrm{Ib}$ where $\mathrm{Ib}$ is the band informativeness, that takes the values of: $1-(2 x[0.5-p])$, being $p$ the proportion of the six Nierembergia varieties containing the band. 


\section{RESULTS AND DISCUSSION}

Ornamental crops involve a wide range of species, most of them are almost unknown at a genetic level. Into this frame, molecular markers procedures play a relevant role in the study of the genetic diversity, in determining cultivar purity and hence leading to improve property rights protection (De Riek, 2001).

Table 1. Molecular identification profile of each $N$. linariaefolia variety obtained with all primers used in the present work. * indicates the presence of a locus in the gel.
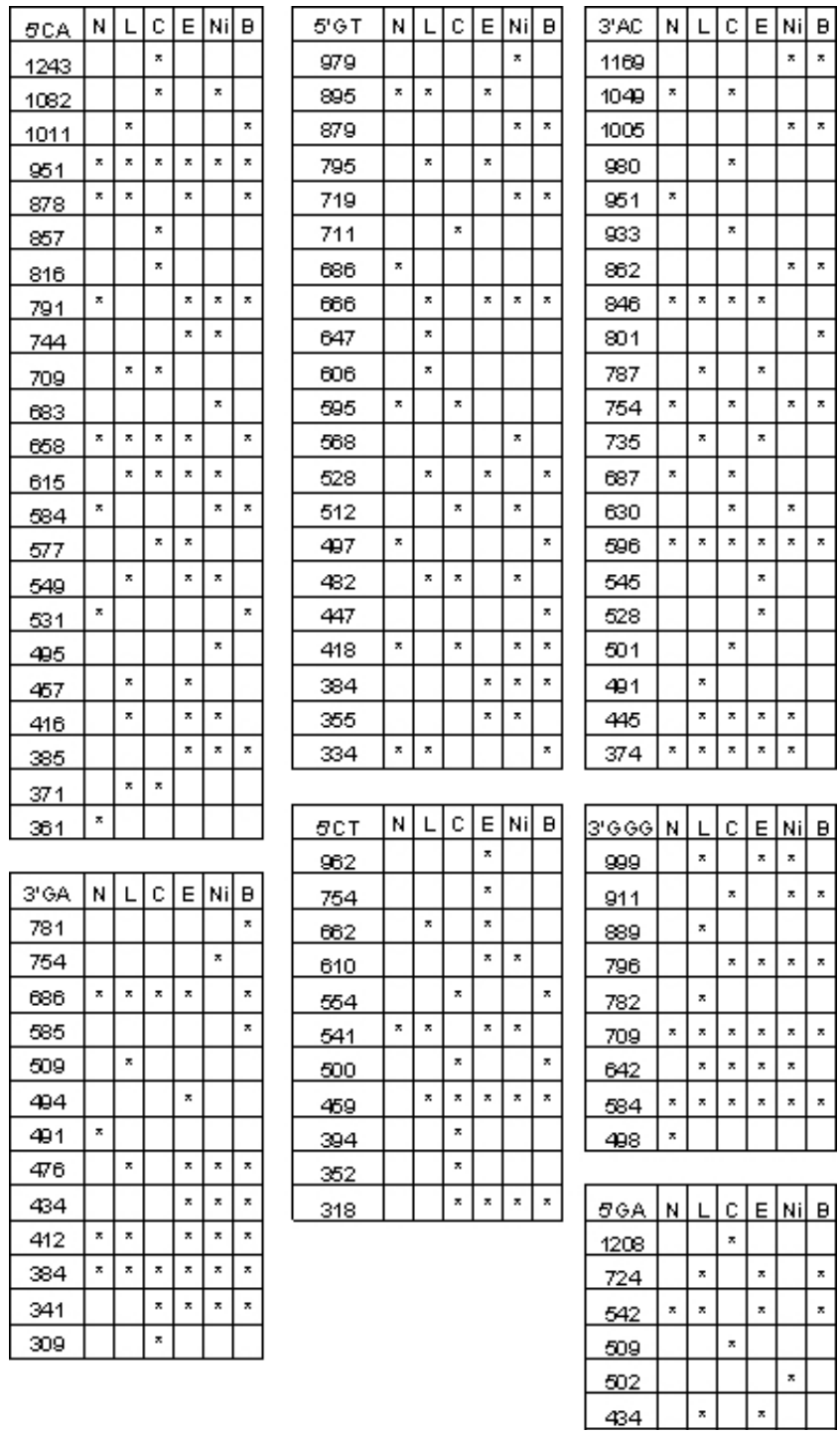

In the present work seven ISSR primers were used to generate fingerprints in selected clones of $N$. linariaefolia. The ISSR primers were described as highly conserved in most of the studied plant genomes (Blair et al. 1999). These authors evaluated the genetic diversity among 59 rice cultivars. Fernández et al. (2002) reported that sixteen barley cultivars were distinguished applying this technique. Jain et al. (1999) evaluated the genetic diversity and generated genome fingerprinting of genus Pandorea. In the same way, Pérez de la Torre et al. (2003) and Escandón et al. 2005a discriminated among 6 and 21 accessions of $J$. mimosifolia respectively.

Figure 1 show, as an example, the amplification profile obtained with the 5'CA, 3'AC and $3^{\prime} \mathrm{GGG}$ primers. The analysis of bands per primer in the present gel, shows, for the primer 5 'CA polymorphic loci in: 1243, 1082, 1011, $878,857,816,791,744,709,683,658,615,584,577,549$, $531,495,457,416,385,371$ and $361 \mathrm{bp}$. For the primer $3^{\prime} \mathrm{AC}$, the bands that revealed polymorphic loci were: 1169 , 1049, 1005, 980, 951, 933, 862, 846, 801, 787, 754, 735, $687,630,545,528,501,491,445$ and $374 \mathrm{bp}$. Finally, the primer 3'GGG shows polymorphic loci at: 999, 911, 889, 796, 782, 642 and 498 bp.

The generated MIP for each variety of $N$. linariaefolia is shown in Table 1.

Table 2 summarized the data obtained: the number of total loci (TL), the number of polymorphic loci (PL), the percentage of polymorphic loci $(\% \mathrm{P})$, the number of different genotypes identified (IG) and the $\mathrm{Rp}$ of each primer. The seven primers used detected a total of 251 loci, $98 \%$ of them were polymorphic, and an average of 41 loci per genotype and 35 loci per primer. The percentage of polymorphic loci ranged from $93.1 \%$ for $3{ }^{\prime}$ GGG to $100 \%$ for $5^{\prime} \mathrm{CT}, 5^{\prime} \mathrm{GT}$ y $5^{\prime} \mathrm{GA}$. Rp ranged from 4.33 for $5^{\prime} \mathrm{GA}$ to 13.67 for 5 'CA (Table 2 ).

Prevost and Wilkinson (1999) reported the Rp as the capacity of a given primer to discriminate among different genotypes. As can be seen in Table 2, with primers that show a $\mathrm{Rp}$ value equal or higher than 4.83 it was possible to discriminate among the six Nierembergia varieties.

Primers 5'CA, 5'GT, 5'CT and $3^{\prime} \mathrm{GA}$ were tested in a previous study with other very related genotypes (Escandón et al. 2005b). The $\mathrm{Rp}$ values obtained in the mentioned report were different of the corresponding values obtained here, being the most dramatic case for primer $5^{\prime} \mathrm{CA}$, that gave a $\mathrm{Rp}$ value of 13.67 in the present study in contrast with a value of 5.5 obtained of the previous report (Escandón et al. 2005b). This fact confirms that the power of a primer to discriminate among different genotypes must be circumscribed to the set of individuals involved in each study.

Together with the stability and the uniformity, to be different is a necessary requisite for a variety registration; the ISSR have shown to be an adequate tool for the differentiation of varieties being a true fingerprint of each genotype. In this report 246 new traits are presented. These traits, together with the morphological ones are excellent tools for the differentiation of Nierembergia varieties 


\section{CONCLUDING REMARKS}

A MIP was obtained for each of the six new varieties of $N$. linariaefolia presented in this paper.

All primers, with exception of $5^{\prime} \mathrm{GA}$ that discriminated among 4 varieties only, were able to distinguish among the genotypes analyzed in this study.

The anchored microsatellites showed to be an economic, fast, and simple technique, besides reproducible and reliable for the generation of fingerprints and the establishment of genetic relations in $N$. linariaefolia.

Table 2. Summary of the results obtained in the construction of a molecular identification profile of new varieties of $N$. linariaefolia. TL: number of total loci, LP: polymorphic loci, \%P: percentage of polymorphic loci, IG: number of genotypes identified per primer and Rp: Resolving power.

\begin{tabular}{|c|c|c|c|c|c|}
\hline Primer & TL & PL & \%P & IG & Rp \\
\hline 5'CT & 25 & 25 & 100,00 & 6 & 5,67 \\
\hline 5'GT & 44 & 44 & 100,00 & 6 & 12,67 \\
\hline 3'GA & 34 & 33 & 97,06 & 6 & 5,67 \\
\hline 5'CA & 57 & 56 & 98,25 & 6 & 13,67 \\
\hline 3'AC & 47 & 46 & 97,87 & 6 & 7,83 \\
\hline 3'GGG & 29 & 27 & 93,10 & 6 & 4,83 \\
\hline 5'GA & 15 & 15 & 100,00 & 4 & 4,33 \\
\hline TOTAL & 251 & 246 & 98,01 & & \\
\hline
\end{tabular}

\section{REFERENCES}

AJIBADE, S.R.; WEDEN, N.F. and CHITE, S.M. Intersimple sequence repeat analysis of genetic relationships in the genus Vigna. Euphytica, 2000, vol. 111, no. 1, p. 47-55.

ALEXANDER, J.A.; LISTON, A. and POPOVICH, S. Genetic diversity of the narrow endemic Astragalus oniciformis (Fabaceae). American Journal of Botany, December 2004, vol. 91, no. 12, p. 2004-2012.

BLAIR, M.W; PANAUD, O. and MCCOUCH, S.R. Intersimple sequence repeat amplification for analysis of microsatellite motif frequency and fingerprinting in rice (Oryza sativa L.). Theoretical and Applied Genetics, April 1999, vol. 98, no 5, p. 780-792.

CENIS, J.L. Nuevas técnicas moleculares para la identificación varietal de plantas. Revista Terralia, 2000, vol. 12 , p. $40-43$.

COCUCCI, A.A. and HUNZIKER, A.T. Nierembergia, In: HUNZIKER, A.T eds. Flora Faneroámica Argentina, Córdoba, Pugliese Siena S.R.L., 1995, vol. 15, p. 3-14.

CIMMYT. Laboratory Protocols: CIMMYT. Applied Molecular Genetics Laboratory. Third Edition, Mexico,
D.F. 2005. 102 p. ISBN 968-6923-30-6. [cited March 2006] Available from

Internet: http://www.cimmyt.org/english/docs/manual/protocols/abc _amgl.pdf.

DE RIEK, J. Are molecular markers strengthening plant variety registration and protection? In: VAN HUYLENBROECK, J. ed. Proceedings XX EUCARPIA Symposium on New Ornamental. Acta Horticulturae (ISHS), 2001, vol. 552, p. 215-223.

ESCANDÓN, A.; PÉREZ DE LA TORRE, M.; ACEVEDO, A.; MARCUCCI-POLTRI, S. and MIYAJIMA, I. Anchored ISSR as molecular marker to characterize different accessions of Jacaranda mimosifolia L Don. Acta Horticulturae (ISHS), 2005a, vol. 683, p. 121127.

ESCANDÓN, A.; PÉREZ DE LA TORRE, M.; SOTO, M.S. and ZELENER, N. Identificación de clones selectos de Nierembergia linariaefolia mediante microsatélites anclados. RIA, 2005b, vol. 34, no. 1, p. 5-17.

FERNÁNDEZ, M.E.; FIGUERAS, A.M. and BENITO, C. The use of ISSR and RAPD markers for detecting DNA polymorphism, genotype identification and genetic diversity among barley cultivars with known origin. Theoretical and Applied Genetics, April 2002, vol. 104, no. 5, p. 845-851.

JAIN, A.; APPARANDA, C. and BHALLA, P. Evaluation of genetic diversity and genome fingerprinting of Pandorea (Bignoniacea) by RAPD and inter-SSR PCR. Genome, 1999, vol. 42, no. 4, p. 714-719.

MCGREGOR, C.E.; LAMBERT, C.A.; GREYLING, M.M.; LOUW, J.H. and WARNICH, L. A comparative assesement of DNA fingerprinting techniques (RAPD, ISSR, AFLP and SSR) in tetraploide potato (Solanum tuberosum L.) germplasm. Euphytica, 2000, vol. 113, no. 2, p. 135-144.

NYBON, H. Comparison of different nuclear DNA markers for estimating intraspecific genetic diversity in plants. Molecular Ecology, May 2004, vol. 13, p. 1143-1155.

PÉREZ DE LA TORRE, M.; ACEVEDO, A.; SERPA, J.C.; MIYAJIMA, I. and ESCANDÓN, A.S. Puesta a punto de la técnica de microsatélites anclados para la caracterización de individuos selectos de jacarandá. In: MASCARINI, L.; VILELLA, F. and WRIGHT, E. eds. Floricultura en la Argentina. Investigación y Tecnología de Producción, 2003, p. 3-12.

PREVOST, A. and WILKINSON, M.J. A new system of comparing PCR primers applied to ISSR fingerprinting of 
potato cultivars. Theoretical and Applied Genetics, January 1999, vol. 98, no. 1, p. 107-112.

UBC, University of British Columbia [online]. [cited June 2005] Available from Internet: http://www.michaelsmith.ubc.ca/services/NAPS/Primer_Se ts/Primers.pdf

WOLFE, A.; XIANG Q-Y. and KEPHART, S.R. Assessing hybridization in natural populations of Penstemon (Scrophulariaceae) using hypervariable inter-simple sequence repeat markers. Molecular Ecology, September 1998, vol. 7, no. 9, p. 1107-1125.

WOLFF, K.; ZIETEKEWICZ, E. and HOFSTRA, H. Identification of chrysantemun cultivars and stability of DNA fingerprinting patterns. Theoretical and Applied Genetics, August 1995, vol. 91, no. 3, p. 439-447.

ZIETKIEWICZ, E.; RAFALSKI, A. and LABUDA, D. Genome fingerprinting by simple sequence repeat (SSR)anchored polymorphism chain reaction amplification. Genomics, March 1994, vol. 20, no. 2, p. 176-183.

ZULOAGA, F. and MORRONE, O. Dicotyledoneae (Fabaceae-Zigophhyllaceae). In: Catálogo de las Plantas Vasculares de la República Argentina II; Missouri Botanical Garden Press, 1999, vol. F-Z, p. 1080-1084. 